\title{
Fine-Grained Sediment Dispersal Along the Calfornia Coast
}

$\checkmark$ ine-grained sediment (silt and clay) enters coastal waters from rivers, eroding coastal bluffs, resuspension of seabed sediment, and human activities such as dredging and beach nourishment. The amount of sediment in coastal waters is an important factor in ocean ecosystem health, but little information exists on both the natural and human-driven magnitudes of fine-grained sediment delivery to the coastal zone, its residence time there, and its transport out of the system-information upon which to base environmental assessments. To help fill these information gaps, the U.S. Geological Survey has partnered with Federal, State, and local agencies to monitor fine-grained sediment dispersal patterns and fate in the coastal regions of California. Results of these studies suggest that the waves and currents of many of the nearshore coastal settings of California are adequately energetic to transport fine-grained sediment quickly through coastal systems. These findings will help with the management and regulation of fine-grained sediment along the U.S. west coast.
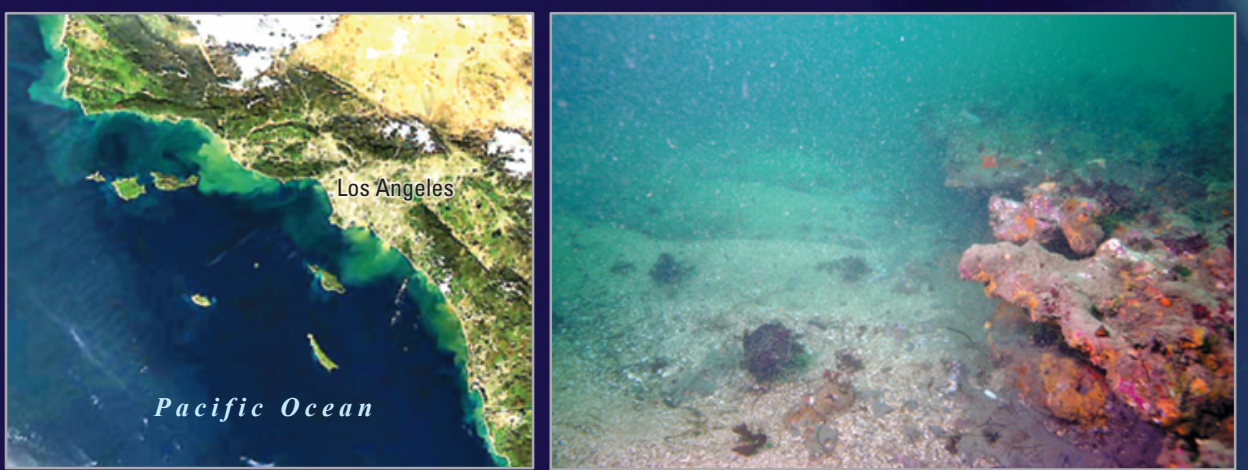

Left, a satellite image showing river-sediment plumes off the southern California coast near Los Angeles. Image courtesy of NASA (National Aeronautics and Space Administration). Right, seafloor habitats near Santa Cruz, California. Photo by Curt Storlazzi.

\section{Sources of Fine-Grained Sediment to the Coast}

The majority of the fine-grained sediment that enters and circulates through the coastal systems of California is part of the natural processes of erosion and transport associated with the geologic cycle that has been active for millions of years. In California, rivers are the dominant source of finegrained sediment that enters the ocean, with an average annual discharge of approximately 34 million tons. The erosion of coastal cliffs and bluffs contributes roughly 3 million tons of fine-grained sediment per year. These natural supplies vastly exceed the combined sediment contributions from human activities, which include damming of rivers, emplacement of harbors, hydraulic mining, watershed land-use changes, and movement and management of coastal sediment. The construction of dams on California rivers has had perhaps the greatest impact on fine-grained sediment transport, resulting in a dramatic reduction in sediment supply to the coast - on the order of 25 to 50 percent since the 1960 s.

\section{Fine-Grained Sediment and Coastal Ecosystems}

Once discharged into the ocean, fine-grained sediment can have significant and important effects on coastal ecosystems, both negative and positive. Turbidity and sedimentation may reduce photosynthesis, decrease visibility for visual feeders, and bury sea-floor habitats. But fine-grained sediment is also an important source of nutrients to estuarine ecosystems, the continental shelf, and the California Current. Additionally, the deposition of fine-grained sediment along coasts may act as a mitigating factor to sea-level rise. These competing concepts of the potential effects of fine-grained sediment on California coastal ecosystems emphasizes the need for a better understanding of the pathways and physical processes of fine-grained sediment delivery, residence times, and dispersal in coastal ecosystems.

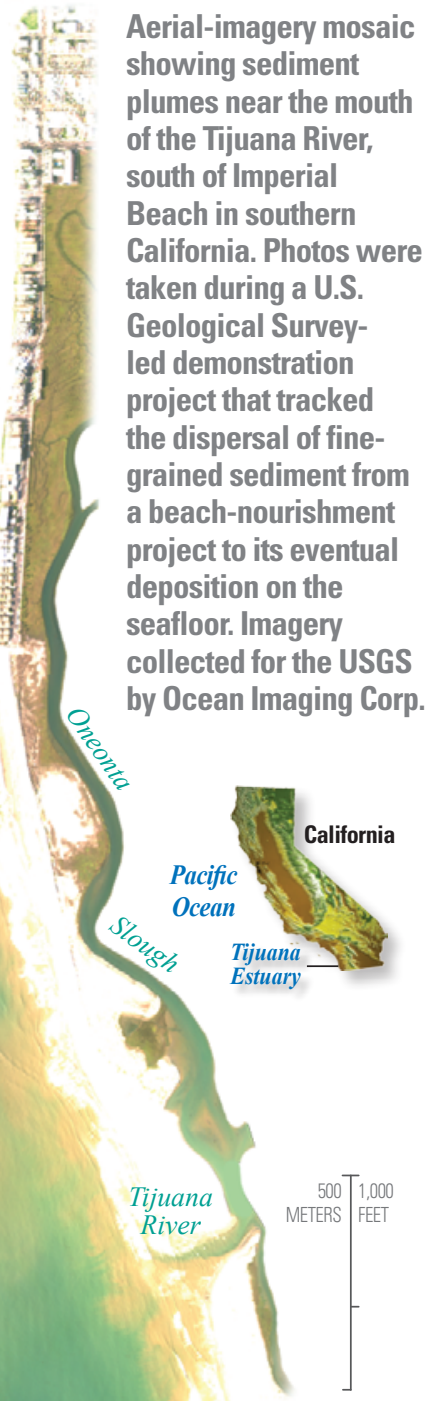


Without a good understanding of these pathways and processes, it will be impossible to predict the potential effects of natural or human changes to the supplies of sediment to coastal waters.

\section{Demonstration Projects}

Two recent demonstration projects, conducted by the Pacific Coastal and Marine Science Center of the U.S. Geological Survey (USGS), with other Federal, State, and local agencies, characterized the dispersal of fine-grained sediment in California coastal waters. These projects, near the mouth of the Tijuana River near San Diego and in Santa Cruz Harbor, focused on the pathways and rates of transport of fine-grained sediment from dredging and beach nourishment. Both projects utilized sediment with greater amounts of finegrained sediment particles-40 and 70 percent by weight - than are traditionally allowed by regulatory agencies during these types of activities. The goals of the two projects were to describe the patterns of water turbidity and sedimentation of the sea floor caused by these sediment sources and to evaluate the effects of environmental parameters like waves, currents, and seabed morphology on these sedimentation patterns. A host of sampling techniques were utilized, including water and sediment sampling by traditional physical techniques, use of optical and acoustic technologies to sample water and seabed-sediment properties, and remote sensing to characterize turbidity plumes.

The general findings of these two projects were similar even though the studies were conducted in different coastal settings. Fine-grained sediment was found to disperse quickly from the release sites and move alongshore and cross-shore to locations away from nearshore rocky habitats. Although turbidity could be extensive during sediment placement, it dissipated within hours to days.
Accumulation of fine-grained sediment on the seabed was negligible in the shallow waters around both project sites. The pathways and rates of sediment movement were related to the size and direction of the waves, strength and direction of the coastal currents, and vertical settling properties of the sediment. Details of these findings and data collected for these projects are available in published reports (see the "Further Reading" section).

\section{USGS Role}

The USGS led the development and implementation of the science plans for both the Tijuana River and Santa Cruz Harbor demonstration projects, and USGS scientists worked closely with project partners to design monitoring plans and led all project sampling. The USGS has been solely responsible for the data collection, analysis, and publication, and USGS scientists are the primary authors of project results.

\section{Santa Cruz Harbor Demonstration Project}

\begin{abstract}
The Santa Cruz
Harbor Demonstration

Project was conducted in 2009 adjacent to the mouth of the Santa Cruz Harbor in central California. This project utilized over 7,600 cubic meters $(\sim 10,000$ cubic yards) of sediment from Arana Gulch that was approximately 70 percent fine-grained by mass. This sediment was placed about 60 meters offshore of the harbor mouth in 2-meter water depth over an interval of two and a half weeks. Sediment was observed to disperse quickly from the placement site on the inner continental shelf and ultimately was transported offshore towards the midshelf mud belt, and there did not appear to be significant net deposition on the seabed in or near the project site.
\end{abstract}

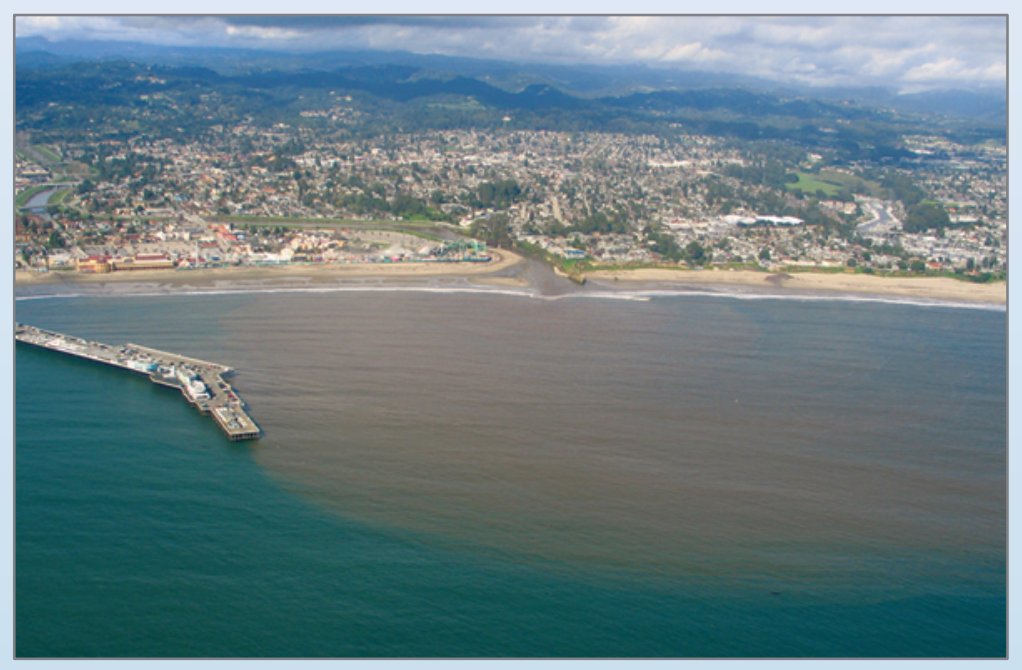

Above, sediment discharged by the San Lorenzo River (less than 1 km upcoast from the Santa Cruz Harbor) into the Monterey Bay National Marine Sanctuary following a storm. Findings regarding sediment dispersal and deposition from dredge disposal projects need to be put into the context of such natural processes.

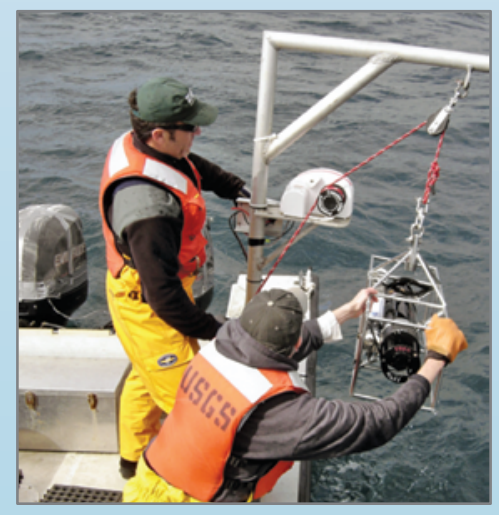

Left, USGS scientists in Santa Cruz Harbor retrieve a grain-sizemeasuring instrument, which uses a laser to determine the size and concentration of sediment particles in the water column.

Right, map of suspened sediment concentration (in grams per liter), calculated by a model over an 18-hour period.
November 5, 2009

Sediment concentration $(\mathrm{g} / \mathrm{L})$

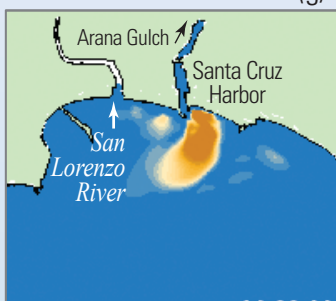

Pacific Ocean 00:00:00
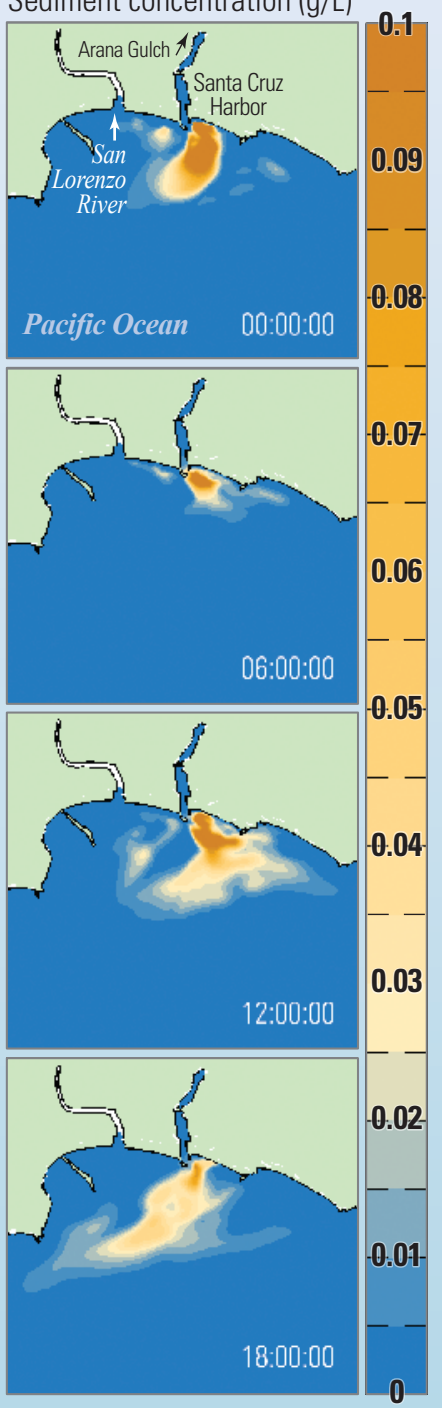


\section{A Few Key Questions about Fine-Grained Sediment}

-What are the pathways and processes of fine-grained sediment in coastal waters?

- How does coastal setting influence these pathways and processes?

-What are the coastal-ecosystem effects of fine-grained sediment?

-Does sediment released by natural processes disperse in fundamentally different ways than sediment released by human activities?

- How do the impacts of fine-grained sediment discharged to the coastal ocean by humans compare to the impacts of fine-grained sediment delivered by natural processes such as river discharge and coastal erosion?

Top, mouth of San Lorenzo River and Santa Cruz Beach Boardwalk. Right, Santa Cruz West Breakwater Light and Yacht Harbor. Photos by Kenneth and Gabrielle Adelman, copyright 2002-2013, California Coastal Records project, www.CaliforniaCoastline.org.
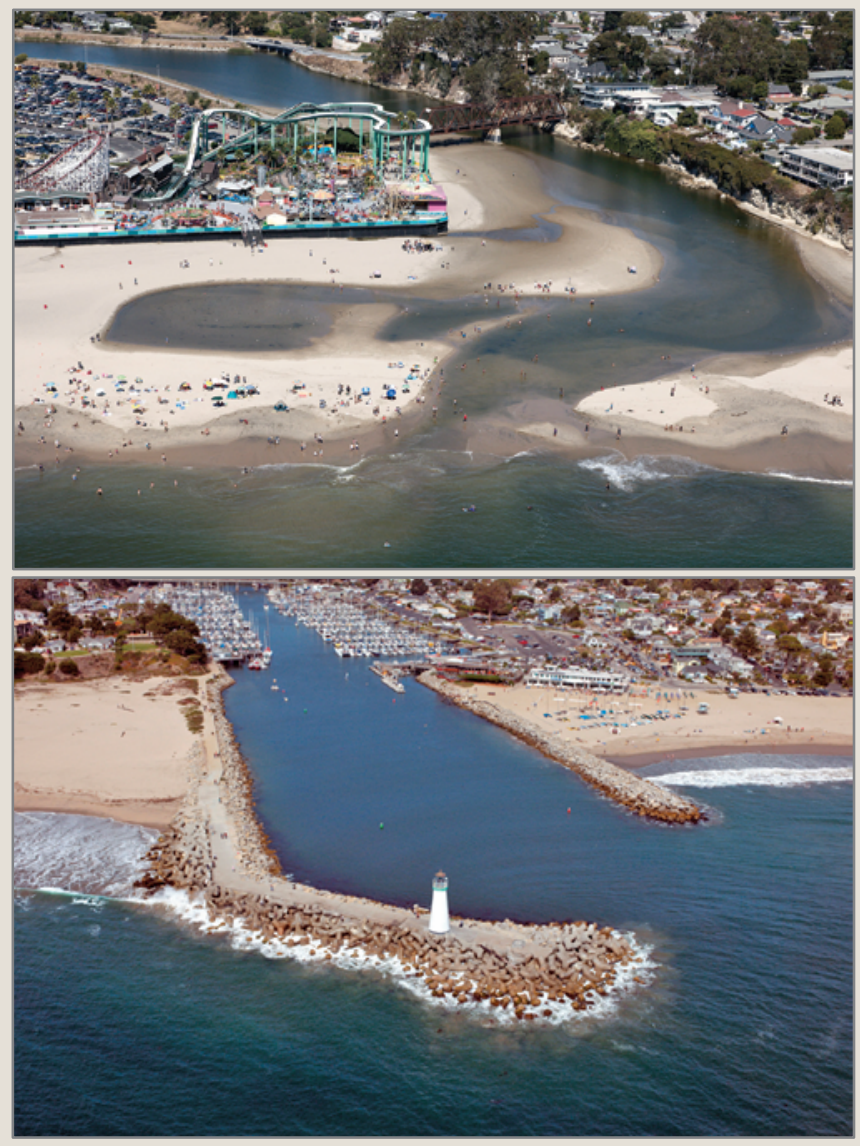

\section{Tijuana River Demonstration Project}

The Tijuana River Demonstration Project was conducted in 2008 and 2009 between the mouth of the Tijuana River, California, and the U.S.-Mexico international border. This project utilized over 34,000 cubic meters (over 40,000 cubic yards) of sediment from a debris basin within Border Field State Park that consisted of approximately 40 percent fine-grained sediment by mass. This sediment was placed directly within the intertidal sandy beach over an interval of several weeks. It was observed to disperse quickly in nearshore waters but was strongly influenced by surf zone currents, which delivered sediment more than 1 kilometer (0.6 miles) up- and downcoast from the emplacement site. Sedimentation in the project area was limited to a zone immediately within and offshore of the project site, and the majority of sediment moved far offshore of the project site in response to waves and currents.

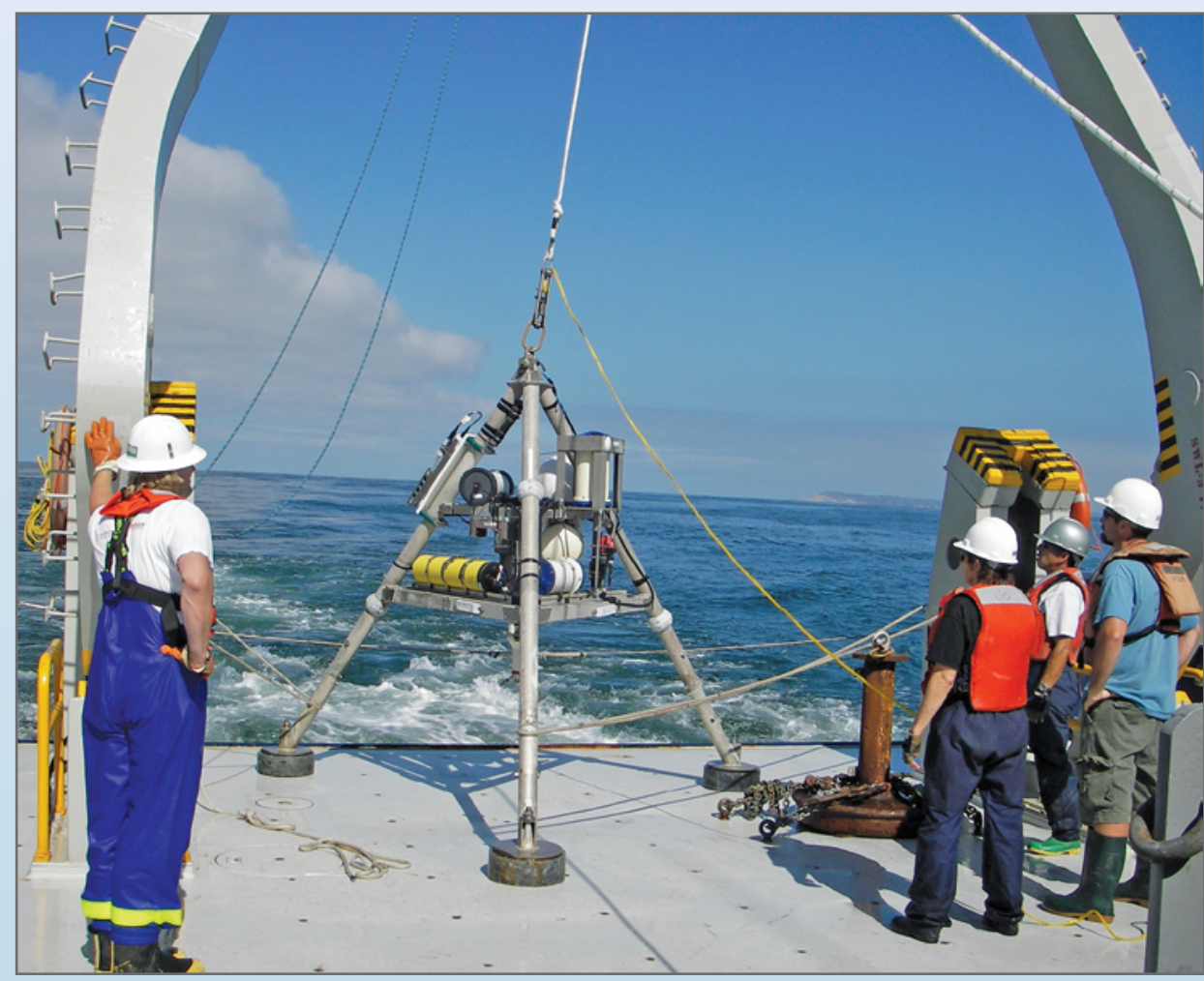

Above, scientists deploy a tripod with instruments to measure the effects of demonstrationproject sediment and environmental conditions on ocean water turbidity.
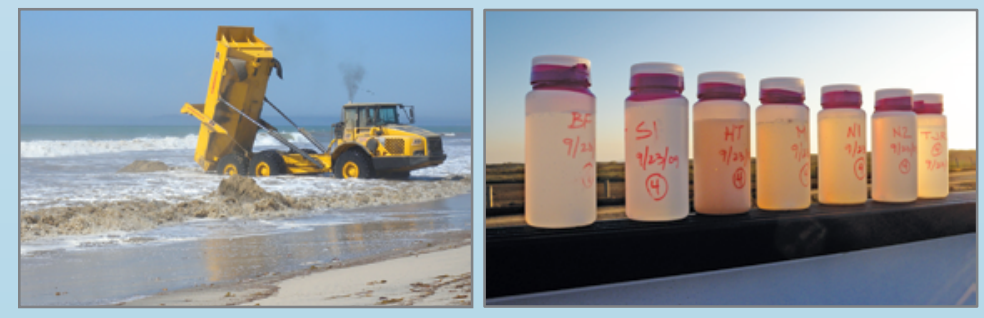

Left, a series of water samples retrieved near the mouth of the Tijuana River. Darker bottles contain more sediment, and samples like these allowed scientists to map patterns of sediment concentration along the coast. Far left, a dump truck adds sediment to the beach near the mouth of the Tijuana River as part of the demonstration project. 


\section{Implementing the Findings}

For monitoring these demonstration projects, the USGS developed new tools, field methods, and analytical techniques that will be applicable to similar studies elsewhere. As part of these efforts, threedimensional physics-based numerical models of sediment movement developed by Deltares and the USGS were used to evaluate the applicability and transferability of the results. The models adequately described directions and rates of fine-grained sediment movement both at the mouth of the Tijuana River and in Santa Cruz Harbor as long as the dominant processes of waves and currents were included in the models and as long as field data on these processes were collected during the demonstration projects to calibrate and validate the models. The field data were also paired with historical climate data to determine if the short-term measurements made during and after sediment emplacement accurately characterized the dynamics of the study site. These findings suggest that future projects to manage and beneficially reuse sediment along the coast of California can utilize these integrated field, laboratory, and numericalmodeling techniques to predict sediment movement and environmental effects under a wide range of coastal conditions and settings. This should allow for better and more efficient sediment management by Federal, state, and local agencies along the broader U.S. west coast.

\section{Further Reading}

Cronin, K., van Ormondt, M., Storlazzi, C.D., Presto, M.K., and Tonnon, P.K., 2011, Nearshore disposal of finegrained sediment in a high-energy environment-Santa Cruz Harbor case study: Coastal Sediments, v. 1, p. 616-627.

Farnsworth, K.L., and Warrick, J.A., 2008, Sources, dispersal, and fate of fine-grained sediment for coastal California: U.S. Geological Survey Scientific Investigations Report 2007-5254, 86 p. Available at http:// pubs.usgs.gov/sir/2007/5254/.

Lescinski, J., Van Ormondt, M., and Warrick, J.A., 2011, Beach nourishment with a high percentage of fine sediments-A modeling study of the Tijuana Fate and Transport Project, California, in Kraus, N.C., and McDougal, W.G., eds., Proceedings of the Seventh International Symposium on Coastal Engineering and Science of Coastal Sediment Processes, v. 1, p. 43-56.

Storlazzi, C.D., and 9 others, 2011, The dynamics of fine-grain sediment dredged from Santa Cruz Harbor: U.S. Geological Survey Open-File Report 2011-1045, 110 p. Available at http:// pubs.usgs.gov/of/2011/1045/.
Warrick, J.A., and 7 others, 2012, Observations of coastal sediment dynamics of the Tijuana Fine Sediment Fate and Transport Demonstration Project, Imperial Beach, California: U.S. Geological Survey Open-File Report 2012-1083, 29 p. and data files. Available at http://pubs.usgs.gov/ of/2012/1083/.

Warrick, J.A., 2013, Dispersal of fine sediment in nearshore coastal waters: Journal of Coastal Research, v. 29, no.3.

\section{Project Research Partners}

\section{Border Field State Park}

California Coastal Conservancy

California Coastal Sediment Management Workgroup California Department of Boating and Waterways California Ocean Protection Council Deltares

Monterey Bay National Marine Sanctuary Ocean Imaging, Inc.

Santa Cruz Port District

Scripps Institute of Oceanography

Southwest Wetlands Interpretive Association Tijuana River Estuarine Research Reserve U.S. Army Corps of Engineers University of California, San Diego University of California, Santa Cruz

\section{Jonathan A. Warrick Curt D. Storlazzi}

Edited by Claire M. Landowski Layout by Jeanne S. DiLeo 